\title{
Biological fieldwork provision in higher education
}

Article

Published Version

Maw, S., Mauchline, A. L. and Park, J. R. (2011) Biological fieldwork provision in higher education. Bioscience Education, 17. 17-1. ISSN 1479-7860 doi:

https://doi.org/10.3108/beej.17.1 Available at http://centaur.reading.ac.uk/20907/

It is advisable to refer to the publisher's version if you intend to cite from the work. See Guidance on citing.

Published version at: http://dx.doi.org/10.3108/beej.17.1

To link to this article DOI: http://dx.doi.org/10.3108/beej.17.1

Publisher: UK Centre for Bioscience, The Higher Education Academy

All outputs in CentAUR are protected by Intellectual Property Rights law, including copyright law. Copyright and IPR is retained by the creators or other copyright holders. Terms and conditions for use of this material are defined in the End User Agreement. 


\section{CentAUR}

Central Archive at the University of Reading

Reading's research outputs online 


\title{
Biological Fieldwork Provision in Higher Education
}

\author{
Stephen J. Maw ${ }^{1}$, Alice L. Mauchline ${ }^{2}$, Julian R. Park² \\ ${ }^{1}$ UK Centre for Bioscience, the Higher Education Academy, Room 9.15, Worsley Building, \\ University of Leeds; ' 2 School of Agriculture, Policy \& Development, University of Reading.
}

\begin{abstract}
Fieldwork is regarded as an important component of many bioscience degree programmes. QAA benchmarks statements refer explicitly to the importance of fieldwork, although give no indication of amounts of field provision expected. Previous research has highlighted the importance of fieldwork to the learning of both subject-specific and transferable skills. However, it is unclear how the amount and type of fieldwork currently offered is being affected by the recent expansion in student numbers and current funding constraints. Here we review contemporary literature and report on the results of a questionnaire completed by bioscience tutors across 33 UK institutions. The results suggest, perhaps contrary to anecdotal evidence, that the amount of fieldwork being undertaken by students is not in decline and that on the whole, programmes contain reasonable amounts of fieldwork. The majority of programmes involved UK-based fieldwork, but a number of programmes also offered 'exotic' overseas fieldwork which was considered important in terms of student recruitment as well as exposing students to a diversity of field learning environments. Tutors were very clear about the benefits of fieldwork and the need to be proactive to maintain its provision.
\end{abstract}

Keywords: Fieldwork, Biology, Survey, Curricula

\section{Introduction}

Fieldwork is considered by many to be an essential part of a bioscience degree and can be an effective and enjoyable part of learning (Fuller et al., 2006; Boyle et al., 2007). Fieldwork provides a novel learning environment (Rickinson et al., 2004; Cotton and Cotton, 2009) which can benefit some students that find other teaching methods, such as lectures or laboratory practicals less rewarding (Kern and Carpenter, 1984; 1986). Fieldwork can also provide a means for developing specialisation within bioscience degrees by training students in practical skills relevant to their chosen discipline. Further to these subject-related benefits, there also seems to be a further 'hidden curriculum' for fieldwork which includes team working, the development of interpersonal skills, self management and lifelong learning skills (Andrews et al., 2003).

Despite these acknowledged benefits, published evidence suggests that bioscience fieldwork is on the decline in both HE (Smith, 2004) and in schools and colleges (Tilling, 2004; Lock, 2010). Recent research into fieldwork provision for 11-19 year olds (Glackin, 2007; Lock, 2010 and references therein) suggests that there is a continuing downward trend. However, the current trend in fieldwork provision in bioscience degree programmes has not been investigated since a survey in 2003 (Smith, 2004).

Fieldwork seems to have maintained its profile within Geography, Earth and Environmental Sciences (GEES) degree programmes (Gold et al., 1991; Kent et al., 1997) with much of the fieldwork literature based in these subjects. This profile has recently led to the publication of two comprehensive guides on the effective teaching of these subjects through fieldwork 
(Butler, 2008; Maskell and Stokes, 2008). However, it has been acknowledged that fieldwork in HE faces similar pressures in both bioscience and GEES disciplines, including: financial considerations, staff time and expertise, increased health \& safety legislation, technological alternatives to fieldwork as well as students' attitudes and their previous experience (Smith, 2004; Boyle et al., 2007).

Over the past few years, the Higher Education sector has been experiencing increased resourcing pressures and fieldwork is viewed by some as an expensive and time-consuming activity which does not fit easily within timetables or indeed resource models. This, combined with a variety of anecdotal evidence, suggests that fieldwork is, or will be, under increased pressure as we move into a further period of severe resource constraint; HEFCE (2010) recently announced a substantial reduction in the recurrent teaching grant for 2010-2011.

In this paper we review the current status of fieldwork in biosciences education via a literature review and survey of lecturers undertaking fieldwork.

\section{Current status of fieldwork in Higher Education}

The number of students enrolling on Biological Sciences HE programmes has been slowly increasing over the period of 2004/05 to 2008/09 (Table 1). This is encouraging in terms of the continuing popularity of bioscience subjects, but increasing student numbers can in itself bring difficulties for fieldwork provision (Jenkins, 1994).

Table 1. Student enrolments on Biological Sciences programmes 2004/05 to 2008/09 in UK HEIs (HESA, 2010)

\begin{tabular}{|c|c|c|c|c|c|c|}
\hline Biological Sciences & $2004 / 05$ & $2005 / 06$ & $2006 / 07$ & $2007 / 08$ & $2008 / 09$ & $\begin{array}{c}\% \text { change } \\
04 / 05 \text { to } 08 / 09\end{array}$ \\
\hline $\begin{array}{l}\text { Postgraduate } \\
\text { Full time }\end{array}$ & 14275 & 14920 & 15940 & 16650 & 18290 & $22 \%$ \\
\hline $\begin{array}{l}\text { Postgraduate } \\
\text { Part time }\end{array}$ & 10180 & 10215 & 10375 & 9940 & 10805 & $6 \%$ \\
\hline $\begin{array}{l}\text { Undergraduate } \\
\text { Full time }\end{array}$ & 100050 & 104580 & 108830 & 111690 & 115545 & $13 \%$ \\
\hline $\begin{array}{l}\text { Undergraduate } \\
\text { Part time }\end{array}$ & 21070 & 21540 & 24305 & 23320 & 27160 & $22 \%$ \\
\hline Totals & 145575 & 151255 & 159450 & 161600 & 171800 & $15 \%$ \\
\hline
\end{tabular}

'Biology and related sciences' is currently offered as a full-time programme at $131 \mathrm{HE}$ institutions in the UK but only at 97 as a part-time programme and it is offered at postgraduate level at 91 institutions for full-time study and at 90 for part-time study (Unistats, 2010).

It is not known how many of the bioscience programmes contain a fieldwork element and there is no formal requirement for fieldwork to be included. The Quality Assurance Agency (QAA) for Higher Education published a benchmark statement for the biosciences (QAA, 2007) to provide a means for the academic community to describe degree programme content and the general expectations of the standards for degree level qualifications. It states that "the biosciences are practical subjects, and cannot be effectively delivered without significant and extensive learning, teaching and experience in a field and/or laboratory environment". There is no minimum amount of practical work expected during a bioscience degree programme, but the benchmark statement describes how fieldwork supports learning by providing opportunities to experience scientific research, data collection \& interpretation and report writing. 


\section{Data survey}

An online, anonymous questionnaire was prepared that aimed to gather data on the amount, type, and extent of fieldwork delivered along with information on some aspects of good practice. The questionnaire was hosted by Bristol Online Services (www.survey.bris.ac.uk) and advertised via the UK Centre for Bioscience's extensive network of contacts who are located in 124 higher education institutions (HEls) which teach a bioscience subject in the UK. (A pdf version of the questionnaire relevant to three-year undergraduate courses can be found in appendix 1.)

The questionnaire was completed during the summer of 2010 by 33 academics from 27 different institutions with respect to 3-year, 4-year undergraduate degrees and MSc degree programmes. The institutions included English, Scottish and Welsh Universities. Nineteen of these were designated before the 1992 Higher Education Acts and 14 were post-1992 institutions. The respondents were mostly programme coordinators with responsibility for organising and teaching the fieldwork element within their respective degree programme(s). The programmes covered included biology, zoology, biochemistry, conservation, geography and ecology. Therefore, the questionnaire responses provide a representative sample of the $\mathrm{HE}$ institutes offering bioscience subjects.

\section{Results}

Where appropriate the results are displayed by 'Year' of the undergraduate degree course: this is defined here as Year $0=$ Scottish first year, Year $1=$ Scottish second year/first year for rest of UK, and so on.

\section{Scope of fieldwork provision}

The number of students enrolled on the 33 bioscience degree programmes covered in this survey ranged widely between programmes and institutions. MSc programmes ranged from 8 to 20 students, whereas undergraduate programmes ranged from 10 to 150 students. All of the questionnaire respondents provided the students with some element of fieldwork within their programmes across the whole range of class sizes.

While only three of the 33 programmes included in this survey had a fieldwork requirement for professional accreditation, over $60 \%$ of the programmes had a compulsory fieldwork element. The programmes varied in attributing between $1 \%$ and $25 \%$ of the overall programme credits to compulsory fieldwork activities.

The provision of timetabled fieldwork was in the form of field days or field courses. Here field days (i.e. usually short day or half-day field work) have been measured in hours, whilst longer multi-day, often residential visits, have been measured in days. The staff:student ratio on these events ranged substantially, from $1: 1$ and 1:40, depending on the nature of the field event (Table 2). The compulsory fieldwork was generally concentrated into the earlier years of the degree programme (Figures 1 and 2). In many cases, less formalised, optional fieldwork took place in the final year of programmes as part of the final year research project. There was a large range between programmes in the time dedicated to fieldwork (Table 2). 


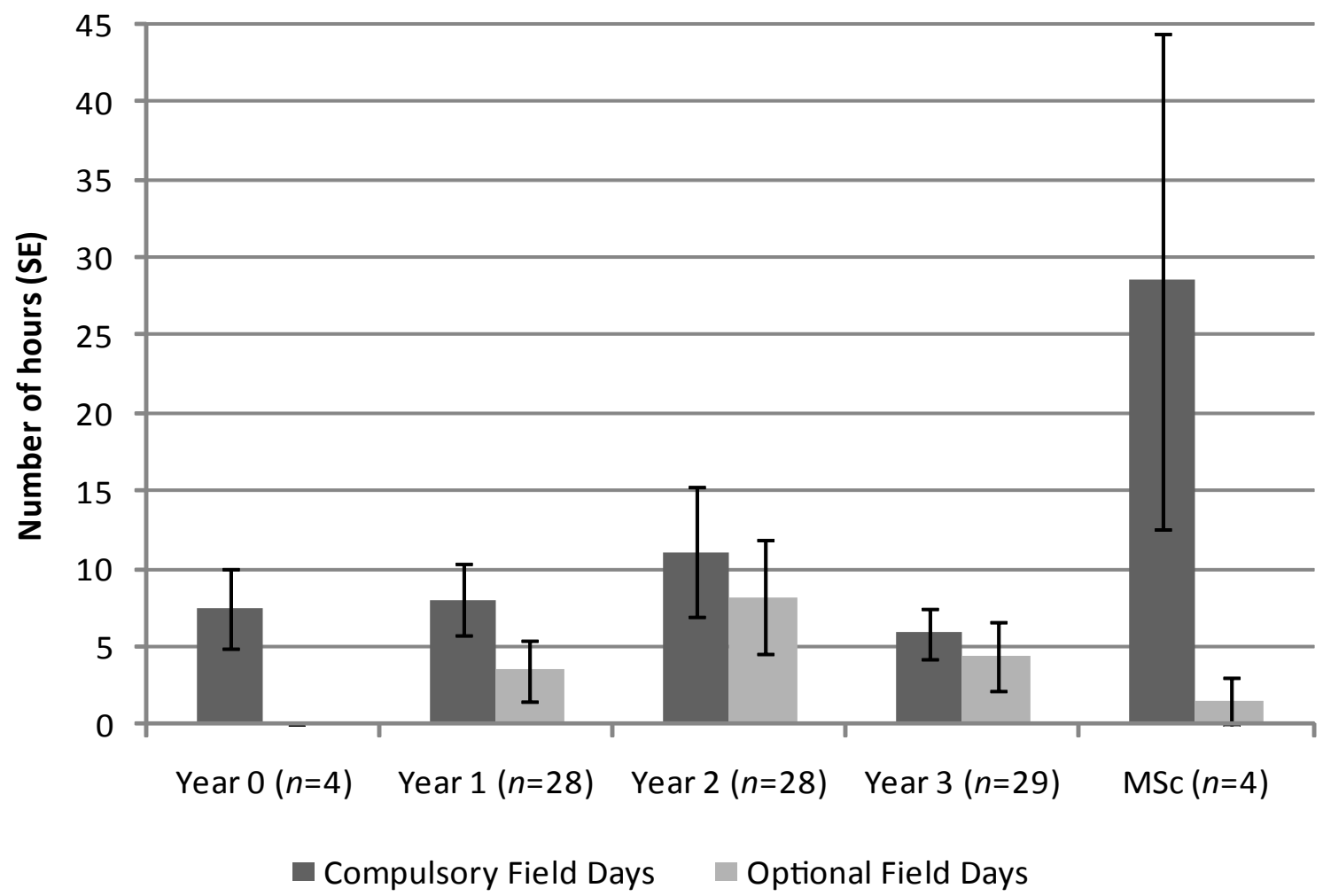

Figure 1. Average number of hours per year spent in the field by each student on compulsory and optional field days throughout their degree course.

(Year 0 = Scottish first year, Year 1 = Scottish second year/first year in rest of UK etc.)

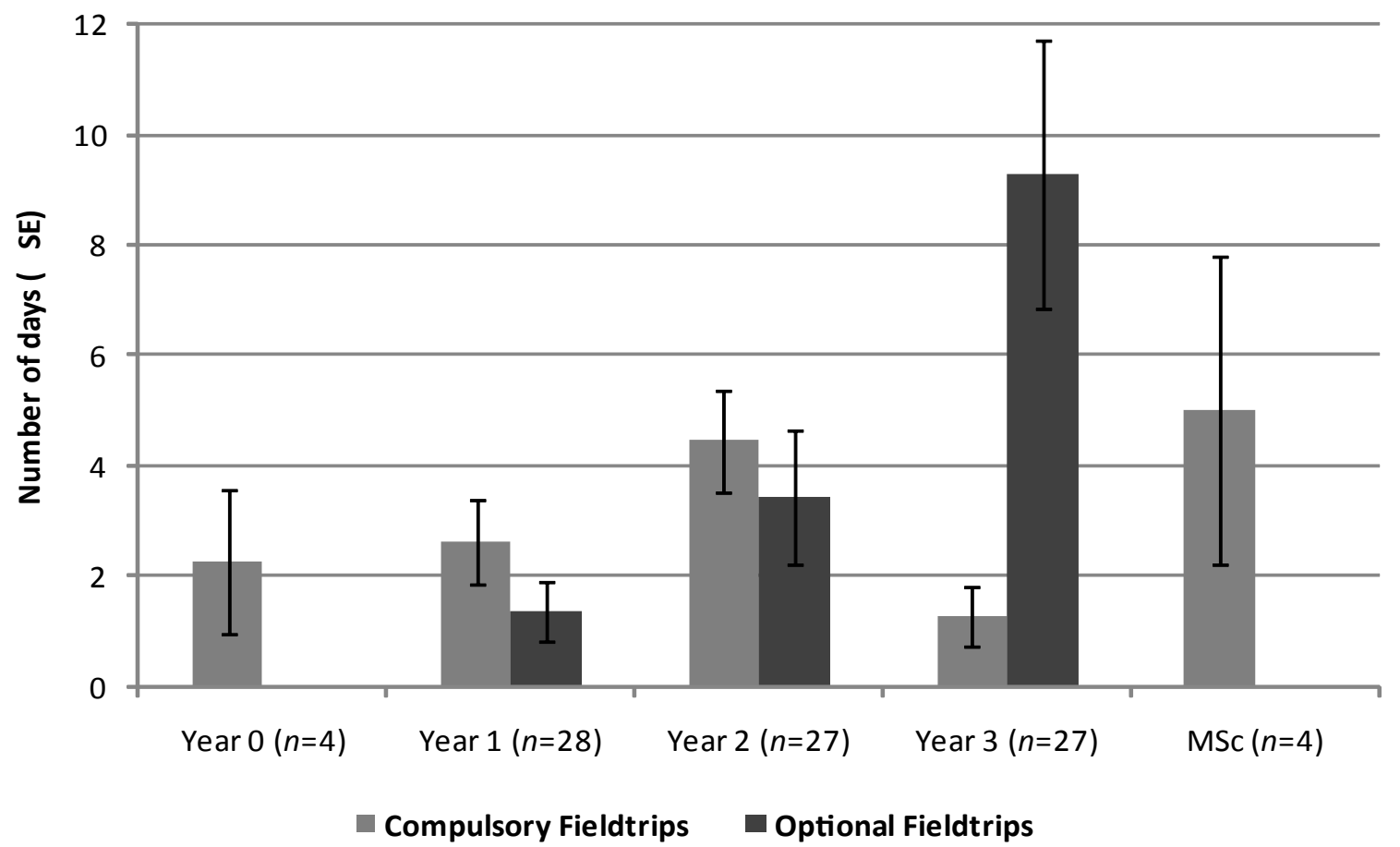

Figure 2. Average number of days per year spent in the field by each student on compulsory and optional field days throughout their degree course.

(Year 0 = Scottish first year, Year 1 = Scottish second year/first year in rest of UK etc.) 
Table 2. Range between degree programmes of the time spent by students on fieldwork per year and staff:student ratios

\begin{tabular}{lcccc}
\hline & \multicolumn{2}{c}{ Undergraduate programmes } & \multicolumn{2}{c}{ MSc programmes } \\
& Time & Staff ratio & Time & Staff ratio \\
\hline Field days (hours) & & & & \\
$\quad$ Compulsory & $0-81$ & $1: 7-1: 20$ & $0-65$ & $1: 4-1: 10$ \\
$\quad$ Optional & $0-80$ & $1: 6-1: 25$ & $0-6$ & $1: 10-1: 20$ \\
Field trips (days) & & & & \\
$\quad$ Compulsory & $0-16$ & $1: 5-1: 40$ & $0-13$ & $1: 4-1: 5$ \\
$\quad$ Optional & $0-42$ & $1: 1-1: 20$ & 0 & - \\
\hline
\end{tabular}

\section{Tutor perceptions}

The top five most important reasons given for retaining fieldwork are summarised below:

1. To experience 'real' biology

2. To learn key practical skills (including taxonomic skills, quantitative methods, observation, field sampling etc.)

3. To enthuse and motivate students

4. To develop group and social cohesion and learning

5. To develop professional skills (including teamworking, presentational skills etc.)

Other reasons given included that fieldwork provides an effective, novel learning environment, it provides opportunities for staff-student interaction and develops a sense of the academic community and that it develops an appreciation for the environment. Fieldwork can also provide the first opportunity for an independent research experience and for putting ecological/ biological theory into practice whilst helping to increase confidence in both academic and transferable skills.

The relevant subject benchmarks for the undergraduate degrees at the different institutions were considered adequate by seven of the respondents but 10 replied saying that it should be more prescriptive with respect to fieldwork. Those that felt it should be more prescriptive indicated that the benchmark statement often mentions fieldwork but falls short of requiring it or setting a minimum amount, however, others felt that being more prescriptive may actually be counter-productive. Nine replied to say that they do not know or that they do not use the subject benchmark in this way.

The majority of respondents felt that fieldwork is essential in achieving learning objectives on their programmes and that it would not be possible to substitute it with other learning activities (average score of $4.67(\sigma=0.540)$ on a scale where $1=$ of no importance up to $5=$ essential, $\mathrm{n}=33$ ). However, some felt that fieldwork could be replaced with virtual fieldwork or lectures to meet the intended learning outcomes, but not that easily (average score of $4.15(\sigma=1.064)$ on a scale where $1=$ extremely easily to $5=$ not possible).

Tutors felt that the amount of fieldwork undertaken by students over the last 5 years has stayed approximately the same (58\%) or even increased $(27 \%)$ with only $15 \%$ of respondents saying it had decreased. A variety of reasons were provided for a change in the amount of fieldwork undertaken by students over the last 5 years, but these were mainly due to the addition or removal of modules or programmes.

\section{Fieldwork skills}

The fieldwork setting provides the opportunity for students to acquire and/or develop key skills. The key groups of skills described by the respondents in order of importance were:

1. Identification/classification

2. Monitoring/sampling/surveying 


\section{Teamworking}

4. Research/experimental design

5. Observation

Problem solving and planning ahead were listed as important skills that fieldwork can engender as these skills are very difficult to develop in planned practical classes in the laboratory and it was felt that the unpredictable nature of fieldwork provides a unique learning environment for developing organisational skills and problem solving abilities. The tutors on the MSc programmes listed further specific skills that they aim to develop during fieldwork including dissection, GPS usage, mapping and describing soil profiles. However, the undergraduate tutors listed other, more generic skills such as project execution, contextualisation of science, application of statistics, report writing, presentation skills and developing an understanding of ethical issues. All of these skills were deemed important, but identification of organisms was highlighted by most of the respondents to be the most important skill that can be learnt during fieldwork as it is "woefully lacking otherwise".

The relative contributions that different categories of staff make towards running and managing field courses are shown in Figure 3. Apart from the categories listed, other contributors included field operatives and counterparts in other countries, former graduates and undergraduates from higher years on the same program, retired staff and friends.

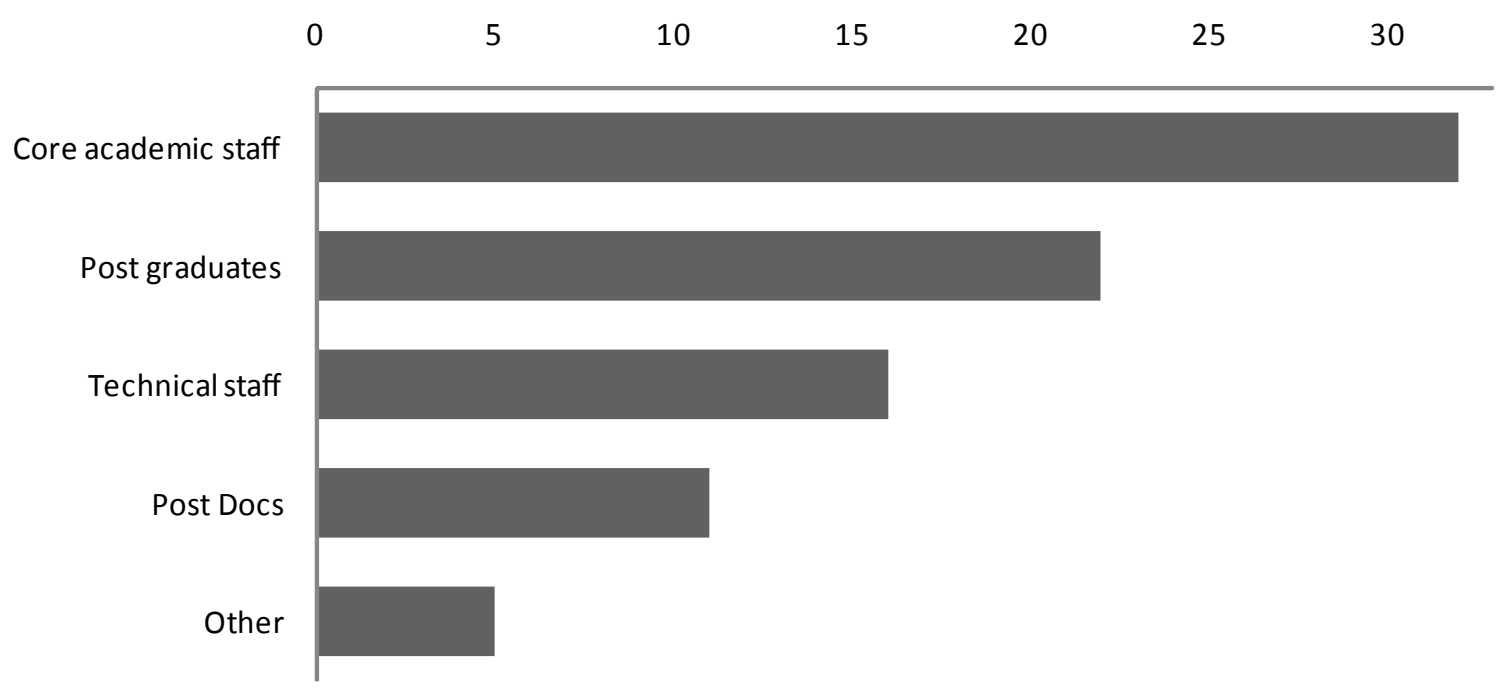

Figure 3 Relative involvement of categories of staff contributing to the running and management of field courses

Tutors were asked to rate a range of statements with regard to the support they get over the need for fieldwork and the responses are summarised in Table 3.

Table 3 Concurrence with statements of support from colleagues over the need for fieldwork in undergraduate and MSc programmes

\begin{tabular}{lccc}
\hline Level of support from colleagues & Agree & Neutral & Disagree \\
\hline $\begin{array}{l}\text { Generally lecturing staff in my department are very supportive of } \\
\text { the need for fieldwork }\end{array}$ & 19 & 6 & 7 \\
$\begin{array}{l}\text { Generally those involved in departmental management are very } \\
\text { supportive of the need for fieldwork }\end{array}$ & 20 & 6 & 6 \\
$\begin{array}{l}\text { The senior management at the university are very supportive of } \\
\text { the need for fieldwork }\end{array}$ & 16 & 10 & 6 \\
\hline
\end{tabular}


Responses to the level of support provided by colleagues was mixed, with senior management seen as the least supportive. At all levels at least half the respondents felt supported but there was a substantial minority (approximately 1 in 5 ) who did not feel they received support for their fieldwork activities.

\section{Timing, location and cost of fieldwork}

Some degree programmes have regular fieldwork sessions that run throughout the academic year. However, only three respondents exclusively organised their fieldwork in this way and intensive field trips or blocks of days were also included on most programmes. There was a strong trend for fieldwork to be conducted outside of term-time in the Easter and summer vacations and institutes often held more than one field trip at different points throughout the academic year (Table 4).

Table 4 Timing of fieldwork during the academic year (categories were scored each time they were mentioned by a respondent) ( $n=33)$

\begin{tabular}{lccc}
\hline Timing of fieldwork & $\begin{array}{c}\text { Undergraduate } \\
(\mathbf{n = 2 9 )}\end{array}$ & $\begin{array}{c}\text { MSc } \\
(\mathbf{n = 4})\end{array}$ & Totals \\
\hline Fieldwork modules throughout the academic year & 11 & 1 & 12 \\
Intensive field trips: & 5 & 1 & 6 \\
During term time between October and Easter & 15 & 2 & 17 \\
At or around Easter but not term time & 8 & 1 & 9 \\
In term time between Easter and the summer & 20 & 1 & 21 \\
vacation & & & \\
In the summer vacation &
\end{tabular}

The institutes in this survey provided a range of locations for fieldwork. Up to 40 locations were used per institute and 146 locations were described overall; of these almost three-quarters (108) were UK-based. The majority of trips were compulsory trips to UK based locations that were free of charge ('free of charge' in the sense that it does not incur costs over and above the normal annual tuition fee) to the student (Figure 4). In addition, fieldwork opportunities were provided in destinations all over the world: overseas locations included several European destinations plus several further afield such as Borneo, Uganda, Tobago, Belize, South Africa, Indonesia and Brazil. A proportion of the cost of the field trips was passed on to the students in some cases (especially for optional overseas trips). In general, compulsory trips required less financial commitment from the student compared to optional trips (Figure 5).

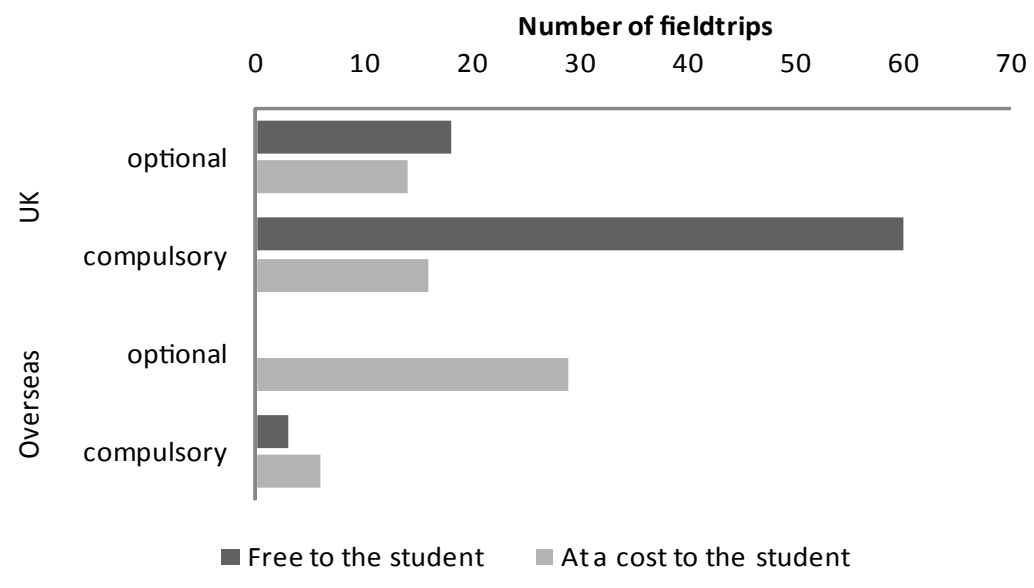

Figure 4 Breakdown of the 146 reported fieldtrips into status and location categories 


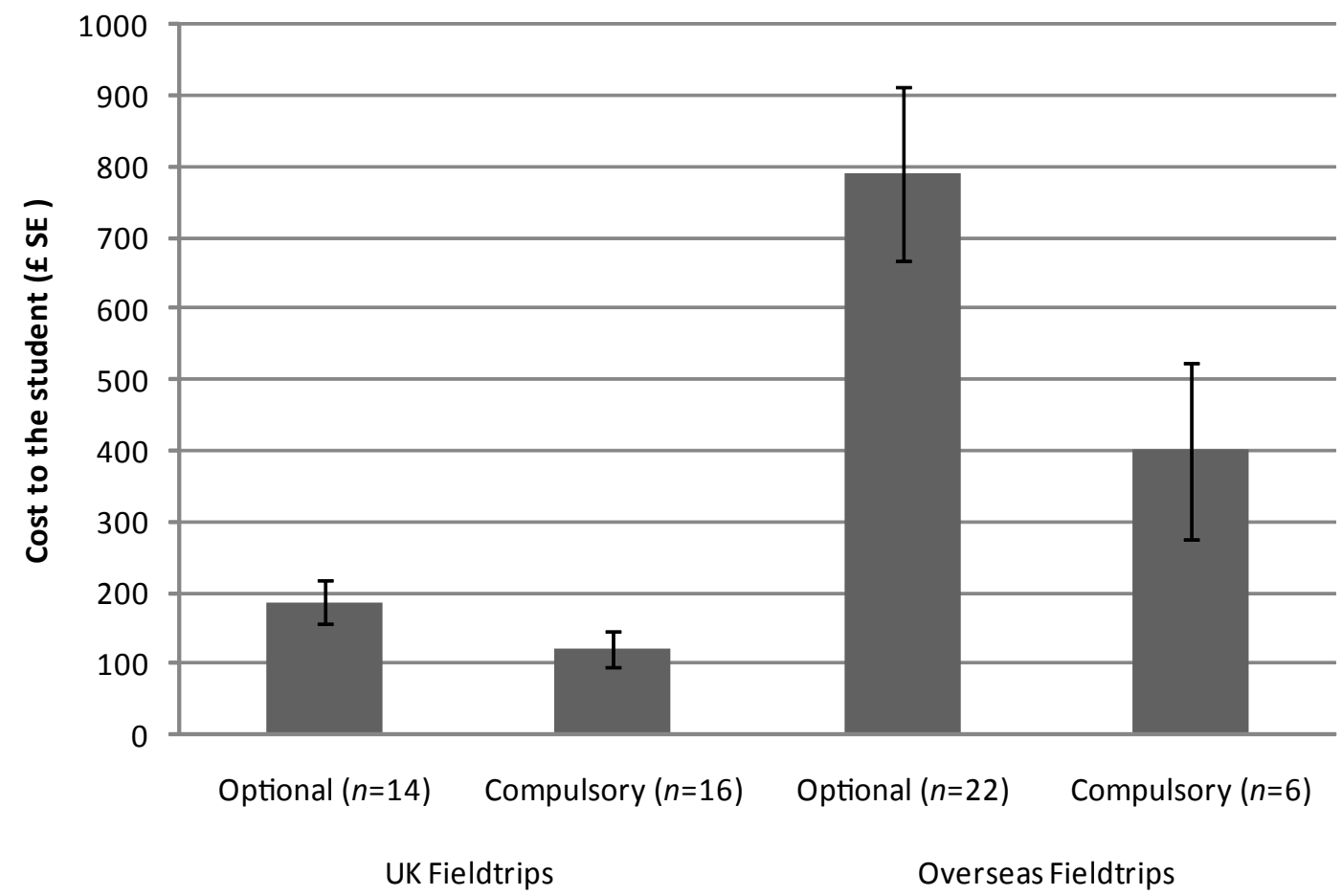

Figure 5 Mean cost to the student per field trip (where applicable) based on approximate costings provided by the questionnaire respondents for most of the fieldtrip locations

In addition to subsidising the whole or part of the cost of the trip, institutes usually provided transport to the fieldwork locations. In general tutors graded the comfort level of the accommodation used for field trips as 'comfortable' some were graded 'very basic' but none graded 'very plush'! If students were expected to pay some or all of the cost of the fieldwork trip they were informed well in advance. The majority were told either at the beginning of the programme or at the beginning of the year and reminded again before departure. Students in financial hardship were offered a range of options (bursaries or hardship funds available and/ or offer flexible (re)payment options ) to help with the costs of fieldwork. Most programmes fully subsidised the compulsory fieldtrips (63 of the 85 compulsory trips were free to the student) while also offering further optional ones for those students that could afford to pay. Three institutes also provided zero/low-cost alternatives (within their local area) in order for all students to gain the essential skills taught during fieldwork.

The tutors were asked to comment on how they believed their students would rate various elements of fieldwork. They all believed that students would highly rate their learning, enjoyment and the social benefits of fieldwork but, as expected, would be much more questioning of the additional financial costs of fieldwork.

\section{Other considerations}

Fieldwork provision was adjusted on a case-by-case basis to account for students with special educational needs. Alternative venues, assessments and/or activities were offered and in some cases a personal helper was provided. The overwhelming response was that everything possible would be and is done to provide all members of the group with a 'valid field experience'. Only a couple of respondents commented that it would not be safe or practical for severely physically disabled students to attempt some of the fieldwork activities. In all cases where this occurred an alternative venue or fieldwork experience was provided. 
In terms of health and safety during fieldwork, most respondents said that they felt adequately trained and $50 \%$ of all leaders were trained in the use of first aid. Field station staff were often relied upon for additional first aid provision and guidance.

\section{Discussion}

\section{Trends in provision}

Contrary to previous reports and current anecdotal evidence we found no evidence from this research that fieldwork in bioscience degree programmes is currently in decline. Tutors reported that the amount of fieldwork undertaken by students over the period 2005-2010 had stayed at approximately the same level or even slightly increased. The results from this survey have shown that fieldwork is still provided on all the bioscience programmes reported on here. This provision was maintained for large class sizes of up to 150 students. This is encouraging given the current trend of rising student numbers (HESA, 2010; Table 1). It has not been possible to ascertain the actual number of biosciences degrees which contain elements of fieldwork, but evidence suggests that programmes such as BSc Biological Sciences, Environmental Biology are likely to contain a compulsory fieldwork element. Indeed $60 \%$ of programmes covered by this survey had a compulsory field element.

\section{Reasons for retention}

Evidence from the survey suggests that fieldwork is being maintained in part because of a fundamental belief of tutors that field provision is a corner stone of learning in relevant bioscience programmes as encapsulated in the quote "working outside and collecting information in a range of environments is the only way the students can apply their theoretical knowledge to real world situations". The general perception is that the 'real world' experience of fieldwork is difficult to replace. There is also some suggestion that fieldwork can provide an important social and developmental experience for students, taking place at a key time in their educational and personal lives.

Conducting field research has been identified as one of the most important skills to equip postgraduates for work in the environmental sector (ERFF, 2010). This skill was also listed as one of the top 15 critical skills that are currently in short supply, yet the report highlights the importance of fieldwork skills in many professions due to the overlap with urgent environmental issues such as climate change, human health and safe energy production. In this survey, tutors identified a range of both subject-specific and generic skills that fieldwork provided, and these combined with the opportunity to work closely with students appear to explain their determination to maintain fieldwork in the curricula. "The field experience is absolutely vital; students learn that it is possible to conduct meaningful experiments/observations in uncontrolled conditions in the field. Furthermore, they learn that 'noise' generated by organisms and their environment is often just as informative as the 'signal' generated by planned manipulations." Indeed many argue that field time is essential to link with theories, techniques and skills that are communicated in the classroom setting; there was a strong feeling that "the field is our laboratory" and "real case studies are in the field". Identification skills were highlighted as the most important skills that could be learnt from fieldwork experience as identification is difficult to teach in the classroom and is a fundamental skill that underpins much of the bioscience field teaching.

Core academic staff were involved in the running and management of fieldwork in all but one of the programmes in the survey with additional support from post docs, post grads, technicians and field centre staff. The coordination of field work therefore offers opportunities for these groups to work and socialise together which provides important teambuilding and learning 
opportunities within academic departments. The informal atmosphere during field learning sessions can also develop student-staff bonds (Boyle et al., 2003; Fuller et al., 2006) which may address some of the issues of student retention and progression. This survey highlighted that tutors are well aware of social importance of fieldwork which enables groups of students to get to know each other well, as well as offering similar opportunities to tutors, encouraging the type of learner tutor networks (as described by Langan et al., 2008) that are important to learning, but which can be difficult to achieve in the formal university setting. It is widely recognised that students also highly rate the social opportunities provided by fieldwork (Boyle et al., 2003; 2007); meaning that fieldwork provision on programmes can help to increase student recruitment.

\section{Location of fieldwork}

Currently, the majority of fieldwork provision is associated with compulsory trips to UK locations. This is probably the cheapest and most time-efficient way to provide large numbers of students with regular fieldwork experience. There is also the argument that graduates from a UK institution should be familiar with some aspect of UK flora and fauna. However, more 'exotic' fieldwork locations can often aid student recruitment (Smith, 2004; and mentioned in one of the survey replies as an important reason to retain fieldwork). Overseas trips can be more expensive and in most cases some or all of this cost is passed on to the student (one optional trip to Indonesia detailed in this survey cost the students $£ 2000$ each to attend). Asking students to make their own way to fieldwork locations is another way in which institutions pass on some of running costs of fieldwork to the students. Although overseas trips provide students with field experiences that are not available in the UK, this benefit needs to be weighed against the environmental impacts of carbon emissions from long-haul flights and the other cultural considerations (Nash, 2000). It is also worth highlighting there is a British Standard (BS8848) (British Standards Institute, 2007) which is applicable to overseas fieldwork and provides a basis for good practice.

\section{Factors influencing fieldwork provision}

Degree accreditation may become more commonplace for bioscience students as the Society of Biology (with BBSRC support) has discussed designing a new programme of degree accreditation. An accredited degree is "one recognised for providing students with the highlevel skills, knowledge and personal attributes required for employment in modern scientific research careers". Such accreditation would provide an assurance to potential employers over the minimum levels of practical and fieldwork experience contained with a degree programme. Fewer than $10 \%$ of the programmes in this survey are currently accredited however, if this percentage increases there may be a consequential influence on the amount of fieldwork contained in degree programmes.

The relevant benchmark statements have the potential to influence the amount of fieldwork contained in degree programmes. While the survey showed that tutors feel that benchmark statements should definitely include a requirement for fieldwork, there was little support for setting a minimum amount. The reasons for this centred around concerns that any threshold could be used by senior management to justify providing an absolute minimum of fieldwork, or, if the threshold was set 'too high' as a reason for no longer offering fieldwork. Many senior managers, possibly even those with a bioscience background, do not have a history or understanding of fieldwork as bioscience covers a wide range of disciplines. It incorporates many sectors that involve laboratory-based research whereas only a few areas such as field biology, environmental biology or ecology have a field-based focus. So whilst those associated with fieldwork feel it is important, it is interesting to note that perhaps there is less support from senior management colleagues. This was mainly due to financial considerations: some reported that fieldwork was given "no support unless cost effective" while others went further 
reporting that senior management felt it was "too costly" or "do not appreciate educational value and have forced the fees for most field courses to be raised excessively". This may be crucial given the period of severe resource constraint we are moving into. Indeed it is interesting to note that much of the costs of field courses are currently absorbed by the university (i.e. are met by the providing School or Department). Some reported pressure to "replace residential field trips with day trips due to the cost of the former". Tutors felt that asking students to pay in situations where this was not the norm could be contentious, although evidence also suggests that some students are willing to pay considerable additional amounts to partake in 'exotic' field trips to all parts of the world.

A key issue for both staff and students is the timing of field studies, and by the nature of the fieldwork being undertaken these usually need to be in the spring and summer. This often means that field trips run in either the Easter or summer vacations, timings which present challenges, perhaps reducing the research time for staff members, or making it difficult for students to hold down paid vacational work. For undergraduate programmes, Year 2 had the highest level of compulsory field days, although a greater amount of optional visits are offered during the final year. This is interesting as this could conflict with periods of heavy student workload and be at a time when they are most in debt. However, students may see the greatest value from fieldwork during the latter part of their studies in terms of final year project completion and employment preparation. A large component of the optional fieldwork provision in Year 3 may well be individual research project work that is a less formalised fieldwork experience, yet of great individual importance in terms of developing independent research skills. The MSc data showed that most of the fieldwork is compulsory which may reflect the more vocational, skill-specific training provided on postgraduate programmes.

\section{Future perspectives}

Virtual fieldwork has been suggested as an alternative to traditional field experiences by simulating field-based activities in a classroom setting. The use of information and communication technology can certainly enhance the field experience and provide methods for student preparation, data collection and collation, gaining access to information remotely, post-fieldwork analysis and feedback (Fletcher et al., 2002; Maskall et al., 2007). However, the response from this survey was that it is not easy to substitute fieldwork with a virtual simulation, which is in line with the general view that it could complement, rather than replace, outdoor fieldwork (Rumsby and Middleton, 2003).

There appear to be a range of possibilities to use technology in terms of better preparing students in advance of field work (McMorrow, 2005), and to ensure maximum benefit is gained when students are in the field (Baggott and Rayne, 2007; Baggott, 2009; Cullen et al., 2007). Certainly the advance in IT and web-based technologies could help to ensure that less able students can experience working in the field (Healey et al., 2002; Fletcher et al., 2002). It was interesting to note in the survey responses a wide range of adjustments made to the provision of fieldwork to accommodate a variety of special educational needs; again flagging the importance tutors place on giving all students the opportunity to "learn in the field". Combined fieldwork across several universities is another approach which currently takes place between some institutions (Smith, 2004) and is an area that other HEls are exploring as a mechanism for rationalising costs.

\section{Conclusions}

Overall, our research suggests that despite a range of pressures on fieldwork, tutors are still enthusiastic and motivated to provide fieldwork for students and this seems to have enabled departments to maintain reasonable levels of provision. The data indicate a range of fieldwork activities are still being undertaken and that the overall level of fieldwork has not decreased in 
the last 5 years although this may mask important changes in the content of fieldwork courses. The reasons for retaining fieldwork reflected a range of benefits: the motivational and social aspects of learning as well as developing generic and subject-specific skills. However, the primary reason was to experience the unpredictable nature of 'real' biology and in doing so provide a unique learning environment.

Increases in class sizes, increased bureaucracy (in terms of risk assessments, health and safety, timetabling issues etc) have not diminished the desire to provide learning in the field opportunities to students. However, the current period of resource constraint is leading to close scrutiny of field provision. There is little doubt it is costly to provide, and few universities will have calculated its real cost in terms of loss of research time for staff etc. Further, key field staff may have already pushed the envelope in terms of maintaining fieldwork in the face of adversity, and thus further pressure may mean that the level and nature of provision requires re-evaluating.

We suggest that more detailed research is required to interpret how levels of fieldwork are being maintained across a spectrum of institutions, whether quality is being maintained and how technology is being used to make field learning more effective. It would also be beneficial to investigate further the "student perspective" on fieldwork from a developmental viewpoint and to explore whether the enthusiasm for fieldwork extends across all of those students who are expected to participate.

Corresponding author: Steve Maw, UK Centre for Bioscience, the Higher Education Academy, Room 9.15, Worsley Building, University of Leeds, Leeds, LS2 9JT. Email: S.J.Maw@leeds.ac.uk Telephone: 01133433002 Fax: 01133435894

\section{Acknowledgements}

The authors would like to thank all those who took the time to complete the online survey and for providing a rich source of current data on which to build this paper.

\section{References}

Andrews, J., Kneale, P., Sougnez, W. , Stewart, M., and Stott, T. (2003) Carrying out Pedagogic Research into the Constructive Alignment of Fieldwork. Planet Special Edition 5, 51-52 available at www.gees.ac.uk/pubs/planet/index.htm (accessed 19 June 2010)

Baggott, G.K. and Rayne, R. C. (2007) The use of computer-based assessments in a field biology module, Bioscience Education E-journal, 9-5 available at www.bioscience.heacademy.ac.uk/ journal/vol9/beej-9-5.aspx (accessed 9 November 2010)

Baggott, G.K. (2009) Fieldwork: E-learning benefits the part-time student. Centre for Bioscience Bulletin, 26, 3 available at www.bioscience.heacademy.ac.uk/ftp/newsletters/bulletin26.pdf

Boyle, A., Conchie, S., Maguire, S., Martin, A., Milsom, C., Nash, R., Rawlinson, S., Turner, A., and Wurthmann, S. (2003) Fieldwork is good? The student experience of field courses.Planet Special Edition 5, 48-51

Boyle, A., Maguire, S., Martin, A., Milsom, C., Nash, R., Rawlinson, S., Turner, A., Wurthmann, S. and Conchie, S. (2007) Fieldwork is good: the student perception and the affective domain. Journal of Geography in Higher Education, 31, 299-317

British Standards Institute (2007) Specification for the provision of visits, fieldwork, expeditions, and adventurous activities, outside the United Kingdom, (BS 8848:2007+Amendment 1:2009) London: $\mathrm{BSI}$

Butler, R. (2008) Teaching Geoscience through Fieldwork. GEES Teaching and Learning Guide. HE Academy Subject Centre for Geography, Earth and Environmental Science 
Cotton, D. R.E. and Cotton, P.A. (2009) Field biology experiences of undergraduate students: the impact of novelty space. Journal of Biological Education, 43, 169-174

Cullen, R., Langan, A.M. and Sen, R. (2007) Using learner response systems for ecological fieldwork. Centre for Bioscience Bulletin, 26, 6-7

ERFF (Environmental Research Funders' Forum) (2010) Most Wanted. Skills Needs in the Environment Sector. ERFF Report 07 available at http://www.nerc.ac.uk/funding/available/ postgrad/skillsreview (accessed 9 November 2010)

Fletcher, S., France, D. Moore, K. and Robinson, G. (2002) Fieldwork education and technology: A GEES perspective. Planet, 4, 17-19

Fuller, I., Edmondson, S., France, D., Higgitt, D. and Ratinen, I. (2006) International perceptions on the effectiveness of geography fieldwork for learning. Journal of Geography in Higher Education, 30 , 89-101

Glackin, M. (2007) Using urban green space to teach science. School Science Review, 89, 29-36

Gold, J.R., Jenkins, A., Lee, R., Monk, J., Riley, J., Shepard, I. and Unwin, D. (1991) Teaching Geography in Higher Education - a manual of good practice. Oxford: Blackwell.

Healey, M., Roberts, C. Jenkins, A. and Leach, J. (2002) Disabled students and fieldwork: Towards inclusivity? Planet, 3, 9-10

HEFCE (2010) Guide to funding: how HEFCE allocates its funds. September 2010/24, Higher Education Funding Council for England 56pp. available at www.hefce.ac.uk/pubs/ hefce/2010/10 24/10 24.pdf (accessed 9 November 2010)

HESA (Higher Education Statistics Agency) www.hesa.ac.uk (accessed 1 August 2010)

Jenkins, A. (1994) Thirteen ways of doing fieldwork with large classes/more students. Journal of Geography in Higher Education, 18, 143-154

Kent, M., Gibertson, D.D. and Hunt, C.O. (1997) Fieldwork in geography teaching: a critical review of the literature and approaches. Journal of Geography in Higher Education, 21, 313-332

Kern, E.L. and Carpenter, J.R. (1984) Enhancement of student values, interests and attitudes in Earth science through a field-orientated approach. Journal of Geography in Higher Education, 21, 313332

Kern, E.L. and Carpenter, J.R. (1986) Effect of field activities on student learning. Journal of Geological Education, 34, 180-183

Langan, A.M., Cullen, R. and Shuker, D. (2008) Student Learning Networks on Residential Field Courses: Does Size Matter? Bioscience Education, 11-1 available at www.bioscience.heacademy. ac.uk/journal/vol11/beej-11-1.aspx (accessed 5 November 2010)

Lock, R. (2010) Biology fieldwork in schools and colleges in the UK: an analysis of empirical research from 1963 to 2009. Journal of Biological Education, 44, 58-64

Maskall, J. Stokes, A., Truscott, J.B., Bridge, A., Magnier, K. and Calderbank, V. (2007) Supporting fieldwork using Information Technology. Planet, 18, 18-21

Maskall, J. and Stokes, A. (2008) Designing effective fieldwork for the Environmental and Natural Sciences. GEES Teaching and Learning Guide. HE Academy Subject Centre for Geography, Earth and Environmental Sciences

McMorrow, J. (2005) Using a web-based resource to prepare students for fieldwork. Journal of Geography in Higher Education, 29, 223-240

Nash, D.J. (2000) Doing independent overseas fieldwork 1: practicalities and pitfalls. Journal of Geography in Higher Education, 24, 139-149

QAA (Quality Assurance Agency) (2007) Subject benchmark statement: Biosciences. QAA 205 12/07. available at www.qaa.ac.uk/academicinfrastructure/benchmark/statements/biosciences 07. asp\#preface (accessed 9 November 2010) 
Rickinson, M., Dillon, J., Teamey, K., Morris, M., Choi, M.Y., Sanders, D. and Benefield, P. (2004) A review of research on outdoor learning. FSC occasional publication 87. Shrewsbury: Field Studies Council available at www.field-studies-council.org/reports/nfer/index.aspx

Rumsby, B. and Middleton, R. (2003) Using C \& IT to support fieldwork on Tenerife. Planet, 5, 4-6

Smith, D. (2004) Issues and trends in higher education biology fieldwork. Journal of Biological Education, 39, 6-10

Tilling, S. (2004) Fieldwork in UK secondary schools: influences and provision. Journal of Biological Education, 38, 54-58

Unistats (2010) http://unistats.direct.gov.uk (accessed 30 May 2010) 